\title{
Methyl and Total Mercury Found in Two Man-Made Amazonian Reservoirs
}

\author{
Helena A. Kehrig, ${ }^{*, a}$ Elisabete F. A. Palermo, ${ }^{a}$ Tércia G. Seixas, ${ }^{a}$ Helder S. B. Santos, ${ }^{a}$ \\ Olaf Malm ${ }^{a}$ and Hirokatsu Akagi ${ }^{b}$
}

${ }^{a}$ Instituto de Biofísica Carlos Chagas Filho, Universidade Federal do Rio de Janeiro, 21941-902 Rio de Janeiro-RJ, Brazil

${ }^{b}$ National Institute for Minamata Disease (NMD) 4058-18, Hama, Minamata, 867-0008, Kumamoto, Japan

\begin{abstract}
Metilmercúrio $(\mathrm{MeHg})$ e mercúrio total $(\mathrm{Hg})$ foram determinados em amostras de água e peixe coletadas em dois reservatórios da Amazônia Brasileira, que apresentam diferentes características limnológicas e ecológicas. As amostras de água de Tucuruí, reservatório mesotrófico com águas claras, apresentaram a concentração de $\mathrm{Hg}\left(12,7 \pm 8,4 \mathrm{ng} \mathrm{L}^{-1}\right)$ superior à encontrada em Balbina $\left(2,2 \pm 0,5 \mathrm{ng} \mathrm{L}^{-1}\right)$, que é um reservatório oligotrófico com águas escuras. Nem Cichla spp. (peixe piscívoro), nem Geophagus surinamensis (peixe onívoro) apresentaram diferença significativa nas concentrações normalizadas pelo comprimento de $\mathrm{MeHg}$ e $\mathrm{Hg}$ no músculo, entre os dois reservatórios. $\mathrm{MeHg}$ e $\mathrm{Hg}$ aumentaram com o peso e o comprimento do Cichla spp. e, também, com o posicionamento trófico na cadeia alimentar. $\mathrm{O}$ fator de bioconcentração (FBC) do $\mathrm{Hg}$ aumentou com o nível trófico dos peixes, do onívoro $\left(10^{3}\right)$ para o piscívoro $\left(10^{4}\right)$. Os peixes de Balbina, ecossistema naturalmente rico em matéria orgânica dissolvida, apresentaram maior FBC. Não somente as diferentes características limnológicas e ecológicas, mas também o hábito alimentar dos peixes parecem ter influência nas concentrações de mercúrio nestes organismos.
\end{abstract}

Methylmercury $(\mathrm{MeHg})$ and total mercury $(\mathrm{Hg})$ concentrations were determined in water and fish samples from two reservoirs within Brazilian Amazon that present different limnological and ecological characteristics. Tucuruí, a mesotrophic reservoir with clear water, presented higher $\mathrm{Hg}$ in water samples $\left(12.7 \pm 8.4 \mathrm{ng} \mathrm{L}^{-1}\right)$ than Balbina $\left(2.2 \pm 0.5 \mathrm{ng} \mathrm{L}^{-1}\right)$, an oligotrophic reservoir with black water. Neither Cichla spp. (piscivorous fish), nor Geophagus surinamensis (omnivorous fish) presented significant differences in length-normalized concentrations of $\mathrm{MeHg}$ and $\mathrm{Hg}$ in muscle, between both reservoirs. $\mathrm{MeHg}$ and $\mathrm{Hg}$ increased with body weight and standard length of Cichla spp., and also with the trophic level on the food chain. The $\mathrm{Hg}$ bioconcentration factor (BCF) increased with the trophic level of the fish, from the omnivorous $\left(10^{3}\right)$ to piscivorous fish $\left(10^{4}\right)$. Fish from Balbina, an ecosystem naturally rich in dissolved organic matter, presented the highest BCF. Not only the different limnological and ecological characteristics but also the feeding habits seem to influence the mercury concentration in fish.

Keywords: limnological and ecological characteristics, hydroelectric reservoirs, bioconcentration factor, abiotic and biotic samples, total and methyl mercury

\section{Introduction}

Methylmercury, the most abundant organic form of mercury in the environment, has been recognised as a serious pollutant of aquatic ecosystems. However limited information about its distribution through the aquatic food chain is available in tropical areas. Methylmercury is largely responsible for the accumulation of mercury in organisms (bioaccumulation) and for

*e-mail: kehrig@biof.ufrj.br the transfer of mercury through the aquatic food chain (biomagnification).

The concentrations of mercury in fish of the Amazonian rivers have been a subject of concern for the health of humans and wildlife for over 15 years. Deforestation for agricultural projects, damming for hydroelectric power plants, and alluvial gold extraction in Amazonia are increasing mercury discharges into aquatic systems, exposing riverine populations to organic mercury (methylmercury) through the consumption of fish. ${ }^{1,2}$ The consumption of fish heavily contaminated with methylmercury may cause adverse effects on human health. 
Numerous researchers have reported the enrichment of methylmercury in fish from newly impounded reservoirs. ${ }^{3-6}$ Recent studies showed that soil and wetland inundation are important sources of mercury as methylmercury to overlying water, as well as to the aquatic food chain. This causes an increase in the mercury level in the food chain, particularly in predatory fish. ${ }^{7}$ The risk of elevated mercury concentrations in fish has become one of the most important issues in assessing the environmental impact of hydroelectric reservoirs. ${ }^{8}$

The elevated mercury concentrations in fish in newly impounded reservoirs are thought to result from an enhancement of the mobility and bioavailability of mercury following flooding. ${ }^{9}$ When a landscape is inundated, organic carbon in the soil and plants is degraded and released into the water. A high amount of organic matter in the water is accompanied by increased decomposition by microbes and consequently on oxygen deficit. It is generally believed that most methylation of $\mathrm{Hg}$ occurs in anoxic environments such as those found immediately following reservoir creation. ${ }^{10}$

Wright and Mason ${ }^{11}$ suggested that mercury and methylmercury bioaccumulation in the presence of large organic compounds occurs through other mechanisms of uptake besides passive diffusion from water to the cells of the organisms. Dissolved organic matter (DOM) interacts very strongly with mercury, affecting its speciation, solubility, mobility and toxicity in the aquatic ecosystems.

Mercury concentrations in many Amazonian soils are naturally high and mercury released from soils into aquatic systems is thought to be higher than the combined input from anthropogenic sources. ${ }^{12}$ Further studies in the 1990s have shown that flooding of both podzolic and peat soil increases mercury methylation. ${ }^{13}$ Roulet et al. ${ }^{14}$ found that the dominant stock of mercury in the Amazon aquatic ecosystem is derived from soil erosion.

There is a need for a basin-wide and systematic approach to sampling and analysis of mercury in fish from different tributaries and reservoirs in the Brazilian Amazon. This means selecting species (or possibly genera) that are representative of the location from which they are captured, and paying attention to factors that are related to the variation in the percentage of total mercury that is present as methylmercury. The present study makes an initial contribution to this task by presenting total mercury and methylmercury data from two reservoirs within the Brazilian Amazon. The present paper adds new insight to existing studies and also complements and compares earlier findings with data generated by this study.

In this study we used two fish species from the Cichlidae family, Cichla spp. (tucunaré) and Geophagus surinamensis (acará), which are endemic in the Amazonian ecosystem and present sedentary and territorial habits. Their preferred habitat is lentic (slow moving) water. They were used as bioindicators of mercury, especially because they integrate mercury over time, in two man-made reservoirs for hydroelectric power plants, Tucuruí and Balbina reservoirs, in the Amazonian basin.

Cichla spp. (tucunaré) are exclusively piscivorous and opportunistic in their feeding habits. ${ }^{15}$ Cichla is useful for this purpose because it is commonly consumed and easily identified (at least to the level of genus). The genus Cichla is comprised of 15 nominal species recognized by external characters, of which colour pattern and meristics are most significant. ${ }^{16}$ Cichla is widely distributed in the Amazon River basin. ${ }^{16}$ This fish is an important food fish in the diet of some Amazonian human populations, being consumed several times a week in several riverine communities. ${ }^{17}$ Its commerce is an important economic activity throughout the region. However, Cichla presents a risk of potentially harmful methylmercury exposure to humans.

Geophagus surinamensis (acará), an omnivorous fish species with a tendency towards herbivory, ${ }^{15}$ is commonly consumed by some Amazonian human populations. G. surinamensis lives in mud and sand-bottomed canals. ${ }^{18}$ G. surinamensis presents a low risk of potentially harmful methylmercury exposure to humans. However, this omnivorous fish presents a high ecological influence on the biotransfer and biomagnification of mercury through the aquatic food chain. ${ }^{19}$ Its commerce is also an important economic activity throughout the region.

The present study was aimed at answering the following question: do different limnological and ecological characteristics influence the assimilation and trophic transference of methylmercury? We also verified if the different limnological and ecological characteristics influence on the concentrations of total mercury in the water column.

For these proposes, we collected samples of water and muscle of two sedentary fish species, Cichla spp. and G. surinamensis at two hydroelectric reservoirs (Balbina and Tucuruí) within the Brazilian Amazon that present different limnological and ecological characteristics. Total mercury and methylmercury concentrations were determined in the abiotic and biotic samples.

\section{Experimental}

\section{Sampling and sampling areas}

In the rainy season of 2000-2001, water and fish samples were collected at two reservoirs (Tucuruí and Balbina) within the Brazilian Amazon with different morphometric 
and limnological characteristics (Figure 1). Table 1 shows some morphometric and limnological characteristics of Tucuruí and Balbina reservoirs, based on literature data. ${ }^{20}$

Muscle samples were collected from 95 specimens of Cichla spp. and 130 specimens of Geophagus surinamensis that were caught with nets or directly acquired from local fishermen. Identification of the fish species was done with the help of the fishermen. Body weight and standard length were measured for every fish, and a piece of dorsolateral muscle tissue was sampled for total mercury and methylmercury analysis. Fishing activity is quite intense

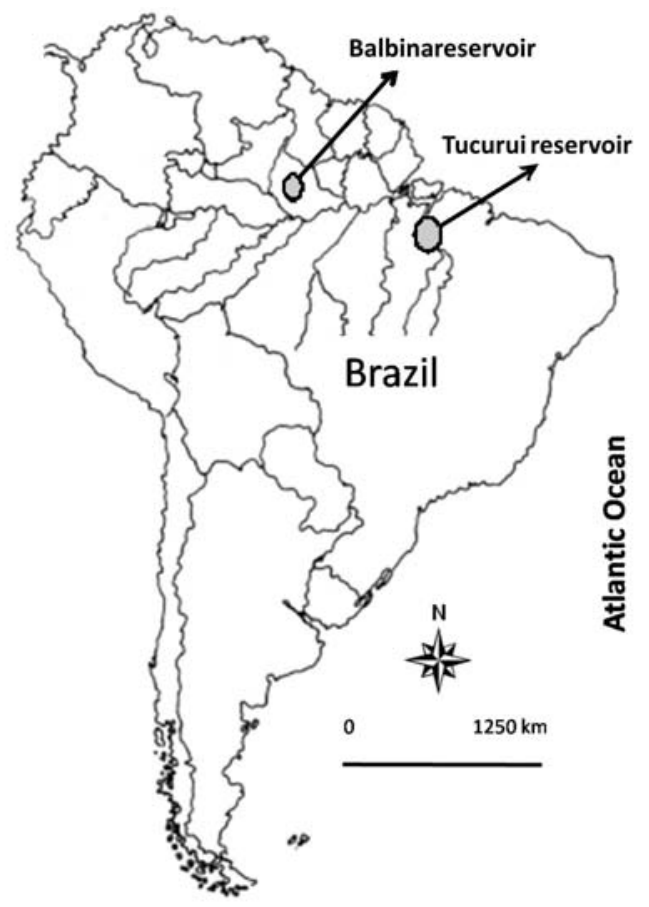

Figure 1. Sampling areas in the Brazilian Amazonian. in both reservoirs, and Cichla spp. is the predominant commercial species caught. Biometric parameters from fish species analyzed (Cichla spp. and G. surinamensis) in this study are presented in Table 2.

The water samples of the surface water column were collected at six areas within both reservoirs, Balbina and Tucuruí. Double-bagged PET bottles (each one with 2.5 L)

Table 1. Morphometric and limnological characteristics of Balbina and Tucuruí reservoirs ${ }^{20}$

\begin{tabular}{lcc}
\hline \multirow{2}{*}{ Characteristics } & \multicolumn{2}{c}{ Reservoir } \\
\cline { 2 - 3 } Localization in the & Balbina & Tucuruí \\
Brazilian Amazon & & Pará \\
(State) & & \\
Latitude & $01^{\circ} 00^{\prime}-02^{\circ} 00^{\prime} \mathrm{S}$ & $03^{\circ} 43^{\prime}-05^{\circ} 15^{\prime} \mathrm{S}$ \\
Longitude & $59^{\circ} 00^{\prime}-60^{\circ} 00^{\prime} \mathrm{W}$ & $49^{\circ} 12^{\prime}$ - $50^{\circ} 00^{\prime} \mathrm{W}$ \\
Main river & Uatumã & Tocantins \\
Operation & Feb 1989 & Marc 1985 \\
Vegetation & Humid forest & Humid forest \\
Drainage area / km ${ }^{2}$ & 18450 & 803250 \\
Retention time / month & 11.7 & 1.7 \\
Inundated area / $\mathrm{km}^{2}$ & 2360 & 2875 \\
Total volume $/ \mathrm{km}^{3}$ & 17.5 & 45.5 \\
Average flow / $\left(\mathrm{m}^{3} \mathrm{~s}^{-1}\right)$ & 577 & 11000 \\
Maximum depth / $\mathrm{m}$ & 30 & 75 \\
Water color & Black water & Clear water \\
Trophic stage of & Oligotrophic & Mesotrophic \\
aquatic environment & & \\
Conductivity / $\left(\mu \mathrm{S} \mathrm{cm}{ }^{-1}\right)$ & 20 & $47-62$ \\
pH & $5.5-6.0$ & $6.5-7.4$ \\
Use & Hydroelectric & Hydroelectric \\
& & production and fishery and fishery \\
\hline
\end{tabular}

Table 2. Biological characteristics of sedentary fish species, Cichla spp. and Geophagus surinamensis, and regression relationships between their body weight $(\mathrm{W})$ and standard length (L). (N corresponds to the number of fish specimens collected)

\begin{tabular}{|c|c|c|c|c|c|}
\hline Species & Sampling area & $\mathrm{N}$ & $\begin{array}{l}\text { Body weight } \\
\text { (min-max) /g }\end{array}$ & $\begin{array}{l}\text { Standard length } \\
\text { (min-max) / mm }\end{array}$ & Relation $\mathrm{W}$ and $\mathrm{L}$ \\
\hline \multirow[t]{3}{*}{ Cichla spp. } & Balbina reservoir & 17 & $\begin{array}{c}400 \\
(97-740)\end{array}$ & $\begin{array}{c}270 \\
(170-515)\end{array}$ & $\begin{array}{c}\log \mathrm{W}=-1.99+1.88 \log \mathrm{L} \\
\mathrm{r}^{2}=0.76 ; p<0.0001\end{array}$ \\
\hline & Tucuruí reservoir & 78 & $\begin{array}{c}400 \\
(117-1682)\end{array}$ & $\begin{array}{c}276 \\
(175-540)\end{array}$ & $\begin{array}{c}\log \mathrm{W}=-0.48+1.23 \log \mathrm{L} \\
\mathrm{r}^{2}=0.51 ; p<0.0001\end{array}$ \\
\hline & Total & 95 & & & $\begin{array}{c}\log \mathrm{W}=-0.74+1.34 \log \mathrm{L} \\
\mathrm{r}^{2}=0.52 ; p<0.0001\end{array}$ \\
\hline \multirow[t]{3}{*}{$\begin{array}{l}\text { Geophagus } \\
\text { surinamensis }\end{array}$} & Balbina reservoir & 11 & $\begin{array}{c}176 \\
(114-350)\end{array}$ & $\begin{array}{c}173 \\
(160-195)\end{array}$ & $\begin{aligned} \log \mathrm{W} & =-5.12+3.28 \log \mathrm{L} \\
\mathrm{r}^{2} & =0.49 ; p<0.01\end{aligned}$ \\
\hline & Tucuruí reservoir & 119 & $\begin{array}{c}137 \\
(41-298)\end{array}$ & $\begin{array}{c}160 \\
(110-200)\end{array}$ & $\begin{array}{c}\log \mathrm{W}=-3.72+2.64 \log \mathrm{L} \\
\mathrm{r}^{2}=0.89 ; p<0.0001\end{array}$ \\
\hline & Total & 130 & & & $\begin{array}{c}\log \mathrm{W}=-3.77+2.67 \log \mathrm{L} \\
\mathrm{r}^{2}=0.91 ; p<0.0001\end{array}$ \\
\hline
\end{tabular}


partially filled with dilute trace metal grade $\mathrm{HCl}$ (Merck p.a.) and arm length poly gloves were used in the sampling. Before each sample was collected, the $\mathrm{HCl}$ (Merck p.a.) was emptied (downstream of collection) and the bottle rinsed three times with ambient water. The sampling bottle was then filled, immediately recapped, double bagged, and stored in the cooler for transport back to the laboratory.

\section{Instrumentation}

Muscle tissue and water samples were analysed for total mercury with a cold vapour atomic absorption spectrometer with a flow injection mercury system (FIMS)- FIAS 400 (Perkin Elmer) with auto sampler AS90 (Perkin Elmer). The carrier gas was argon (99.998\%) at a flow rate of $75 \mathrm{~mL} \mathrm{~min}{ }^{-1}$. For methylmercury analysis, the chromatographic system used was a 14 B Shimadzu gas chromatograph (GC) with a pulsed current ${ }^{63} \mathrm{Ni}$ electron-capture detector-ECD (Kyoto, Japan) equipped with a Shimadzu C-R6A Chromatopac integrator and a GC silane-treated glass column of $1 \mathrm{~m} \times 3 \mathrm{~mm}$ i.d. (GL Sciences Japan) with Hg-20A as stationary phase on 60-80 mesh Uniport HP (GL Sciences, Japan). On the top of column, nearest the injection port, $0.2 \mathrm{~g}$ of $\mathrm{NaCl}$ crystals were added to enhance the methylmercury detection. This method is based on the fact that methylmercury dithizonate in the final solution in toluene is converted into its chloride form as soon as it passes through the $\mathrm{NaCl}$ on the top of the columns. ${ }^{21}$ The column oven, detector and injector temperature were maintained at $150{ }^{\circ} \mathrm{C}, 250{ }^{\circ} \mathrm{C}$ and 180 ${ }^{\circ} \mathrm{C}$, respectively. The carrier gas was nitrogen (99.999\%) at a flow rate of $40 \mathrm{~mL} \mathrm{~min}^{-1}$.

\section{Analytical procedure}

\section{Total mercury analysis in water samples}

The determination of $\mathrm{Hg}$ concentration was performed on two aliquots of unfiltered water samples $(2.0 \mathrm{~L})$. The sample was mixed well with $10 \mathrm{~mL}$ of $\mathrm{H}_{2} \mathrm{SO}_{4}$ (Merck p.a.) and $5 \mathrm{~mL}$ of $0.5 \% \mathrm{KMnO}_{4}$ (Merck p.a.) solution, and allowed to stand for $5 \mathrm{~min}$. The sample was neutralized with $20 \mathrm{~mL}$ of $10 \mathrm{~mol} \mathrm{~L}^{-1} \mathrm{NaOH}$ (Merck p.a.) and $5 \mathrm{~mL}$ of $10 \%$ hydroxylamine hydrochloride (Merck p.a.) and allowed to stand for $20 \mathrm{~min}$. After addition of $5 \mathrm{~mL}$ of $10 \%$ EDTA tetrasodium salt (Dojindo p.a.), the mercury was extracted with $10 \mathrm{~mL}$ of $0.01 \%$ dithizone (Merck p.a.) in toluene (Tedia ABSOLV) purified with an equal volume of $0.1 \mathrm{~mol} \mathrm{~L}^{-1} \mathrm{NaOH}$ (Merck p.a.) just before use. An aliquot $(5 \mathrm{~mL})$ of the organic layer was transferred into a $50 \mathrm{~mL}$ centrifuge tube and dried using a rotary evaporator. The residue in the tube was acid digested for total mercury analysis following the same procedure as that used for biological samples. ${ }^{22}$ Analytical blanks were prepared in a similar way without addition of the analytes.

\section{Total mercury analysis in fish muscle samples}

Total mercury was determined in three aliquots of approximately $500 \mathrm{mg}$ of wet samples of muscle. The sample was acid digested with $3 \mathrm{~mL}$ of $\mathrm{H}_{2} \mathrm{SO}_{4}: \mathrm{HNO}_{3}$ $(1: 1, \mathrm{v} / \mathrm{v})$ (Merck p.a.) and $1 \mathrm{~mL}$ of conc. $\mathrm{H}_{2} \mathrm{O}_{2}$ (Merck p.a.) in a $50 \mathrm{~mL}$ centrifuge tube at $60{ }^{\circ} \mathrm{C}$ in water bath for $45 \mathrm{~min}$. After addition of $5 \mathrm{~mL}$ of $5 \% \mathrm{KMnO}_{4}$ (Merck p.a.) solution, the digested sample allowed to stand overnight. Total mercury $(\mathrm{Hg})$ concentrations in the acid digested solution were determined by CVAAS (FIMS-system) with sodium borohydride (Merck p.a.) as a reducing agent. ${ }^{22}$ Analytical blanks were prepared in a similar way without addittion of the analyte.

\section{Methylmercury analysis in muscle tissue of fish samples}

For methylmercury $(\mathrm{MeHg})$, we used an analytical procedure developed at the National Institute for Minamata Disease (NIMD) laboratory and adapted at the UFRJ laboratory. The methylmercury analysis in muscle tissue of fish was made by a combination of the dithizone-toluene extraction and GC-ECD analysis.22

Methylmercury was performed in two aliquots of approximately $500 \mathrm{mg}$ of wet samples of muscle. Sample was digested with $10 \mathrm{~mL}$ of $1 \mathrm{~mol} \mathrm{~L}^{-1}$ alcoholic potassium hydroxide solution in a $50 \mathrm{ml}$ screw-capped centrifuge tube at $100^{\circ} \mathrm{C}$ in water bath for $45 \mathrm{~min}$. The digested sample was slightly acidified with $10 \mathrm{~mL}$ of $1 \mathrm{~mol} \mathrm{~L}^{-1} \mathrm{HCl}$ (Merck p.a.). After washing with $5 \mathrm{~mL}$ of $n$-hexane (Tedia ABSOLV) the methylmercury was extracted with $10 \mathrm{~mL}$ of $0.05 \%$ dithizone (Merck p.a.) in toluene (Tedia ABSOLV) purified with an equal volume of $0.1 \mathrm{~mol} \mathrm{~L}^{-1} \mathrm{NaOH}$ just before to use. The organic layer was then washed twice with $5 \mathrm{~mL}$ of $1 \mathrm{~mol} \mathrm{~L}^{-1} \mathrm{NaOH}$ to remove the excess dithizone. An aliquot $(5 \mathrm{ml})$ of the organic layer was back extracted with $2 \mathrm{~mL}$ of $0.01 \% \mathrm{Na}_{2} \mathrm{~S}$ in $0.1 \mathrm{~mol} \mathrm{~L}^{-1} \mathrm{NaOH} /$ ethanol $(1: 1 \mathrm{v} / \mathrm{v})$. The excess sulphite ions from the methylmercury solution were eliminated with continuous bubbling $\left(50 \mathrm{~mL} \mathrm{~min}^{-1}\right)$ with $\mathrm{N}_{2}$ gas and some drops of $1 \mathrm{~mol} \mathrm{~L}^{-1} \mathrm{HCl}$ for a further $5 \mathrm{~min}$. To the sample solution, $2 \mathrm{~mL}$ of Walpole's buffer ( $\mathrm{pH}$ 3.0) was added. Walpole's buffer was made with $600 \mathrm{~mL}$ of Milli $\mathrm{Q}$ water $+200 \mathrm{~mL}$ of $1 \mathrm{~mol} \mathrm{~L}^{-1} \mathrm{CH}_{3} \mathrm{COONa}+200 \mathrm{~mL}$ of $1 \mathrm{~mol} \mathrm{~L}^{-1} \mathrm{HCl}$. The methylmercury from this inorganic layer was re-extracted with $1 \mathrm{~mL}$ of $0.05 \%$ purified dithizonetoluene. The organic layer was then washed twice with $2 \mathrm{~mL}$ of $1 \mathrm{~mol} \mathrm{~L}^{-1} \mathrm{NaOH}$ to remove the excess dithizone and subsequently with $5 \mathrm{~mL}$ of distilled water and acidified with a few drops of $1 \mathrm{~mol} \mathrm{~L}^{-1} \mathrm{HCl}$ followed by GC-ECD. ${ }^{22}$ 
Optimization of the analytical protocol and quality assurance tests were carried out using the reference materials (CRM) of fish tissues from the National Research Council-Canada (DORM-2, dogfish muscle sample) and from the International Atomic Energy Agency: IAEA IAEA 350 (tuna fish). Certified reference materials, IAEA350 and DORM-2 were analyzed in all sample batches. Analytical methylmercury quality was certified through inter-comparison exercises between the National Institute for Minamata Disease (NIMD) and the UFRJ laboratories.

\section{Normalization of the total mercury and methylmercury data}

Total mercury and methylmercury concentrations in the Cichla spp. and Geophagus surinamensis muscle were subjected to length normalization, in order to compare their levels between the Balbina and Tucuruí reservoirs, due to the different mean body weights and standard lengths of the fish collected at the various locations (see Table 2).

\section{Statistical Analysis}

Statistical analyses were performed using STATISTICA ${ }^{\circledR}$ 7.0 for Windows (StatSoft, Inc. 1984-2004, USA). Data were tested for normal distributions (Shapiro-Wilk's test) and non-parametric tests were then applied. The analysis of variance was done by Kruskal-Wallis ANOVA followed by a post-hoc test (Mann-Whitney $U$-test). The $U$-test was used to compare the concentrations of total mercury and methylmercury normalized to a standard length and the percent methylmercury of total mercury in muscle tissue of fish with different feeding habits from the two reservoirs. A linear regression was performed to determine the relationship between the biological parameters (body weight or standard length) and the concentrations of total mercury and methylmercury in muscle tissue. A $p$ value of less than 0.05 was chosen to indicate statistical significance. Values are presented as mean \pm standard deviation (SD) based on a wet weight basis (wet wt.).

\section{Results and Discussion}

\section{Detection limit and validation of the analytical method}

The detection limit (LOD) was calculated based on the standard deviation of 20 readings obtained for the analytical blanks and the slopes of the analytical curves $(\mathrm{LOD}=$ 3 s/slope). For total mercury, its value was: $0.00174 \mathrm{mg} \mathrm{L}^{-1}$.

For $500 \mathrm{mg}$ of wet muscle sample, the detection limit for total mercury and methylmercury in fish was $0.042 \mu \mathrm{g} \mathrm{g}^{-1}$ and $0.0005 \mu \mathrm{g} \mathrm{g}^{-1}$, respectively.
The experimental results for total mercury and methylmercury in the certified reference materials (CRM) from the NRCC (DORM-2) and IAEA (IAEA 350) presented good agreement with the certified values, as presented in Table 3. The standard deviations found for experimental values were low and close to those found for certified values, indicating the high reproducibility of the analytical method (Table 3 ). The coefficient of variation $[(\mathrm{SD} \times 100) /$ mean] for each reference sample was lower than $10 \%$, showing that the analytical procedure was satisfactory. According to these results, we can conclude that the analytical method was efficient and reproducible for total mercury and methylmercury determinations in biological tissues, as verified through analysis of the certified reference materials.

Table 3. Analytical results for the determination of certified reference materials $(\mathrm{N}=$ number of samples analyzed in this study)

\begin{tabular}{lccc}
\hline & $\begin{array}{c}\text { Certified Values / } \\
\left(\mathrm{mg} \mathrm{kg}^{-1} \text { dry wt. }\right)\end{array}$ & $\begin{array}{c}\text { Found Values / } \\
\left(\mathrm{mg} \mathrm{kg}^{-1} \text { dry wt. }\right)\end{array}$ & $\mathrm{N}$ \\
\hline DORM - & $4.64 \pm 0.26$ & $4.60 \pm 0.45$ & 20 \\
$\mathrm{Hg}$ & $4.47 \pm 0.32$ & $4.39 \pm 0.46$ & 7 \\
$\mathrm{MeHg}$ & $3.65 \pm 0.35$ & $3.59 \pm 0.38$ & 39 \\
\hline IAEA 350 & & & \\
MeHg &
\end{tabular}

Analytical quality for methylmercury was assured by means of inter-laboratory comparison exercises between the National Institute for Minamata Disease (NIMD) and UFRJ laboratories using fish samples from the Balbina reservoir. Methylmercury results for the analysis performed at the two laboratories for 32 fish samples exhibited highly significant coefficients of correlation $\left(\mathrm{R}^{2}=0.99\right)$. The gradient of the regression line representing the relationship between analyses in the two laboratories was close to 1 (slope, $\beta=1.05$ ).

\section{Unfiltered water samples}

Mercury concentrations of unfiltered Balbina and Tucuruí waters are low (Table 4). Lago Manso, another newly impounded man-made Brazilian reservoir, also presents low mercury concentration in its water samples (3.3 ng L $\left.{ }^{-1}\right) .{ }^{6}$ Generally, total $\mathrm{Hg}$ concentrations in surface waters of the Amazon basin range from 1 to $30 \mathrm{ng} \mathrm{L}^{-1}$, although higher concentrations may be found immediately downstream of gold mining sites or other $\mathrm{Hg}$ pollution sources as well as with high loads of suspended matter. ${ }^{23}$ In the region of Petit-Saut hydroelectric reservoirs, French Guiana, close to an area of gold mining activities, total $\mathrm{Hg}$ 
Table 4. Mean and range (min-max) of total mercury $(\mathrm{Hg})$ and methylmercury $\left(\mathrm{MeHg}\right.$ ) concentrations ( $\mu \mathrm{g} \mathrm{g}^{-1}$ wet wt.), the ratios of methylmercury to total mercury $(\mathrm{MeHg} / \mathrm{Hg}$ ), the mean total $\mathrm{Hg}$ and $\mathrm{MeHg}$ concentrations normalized to a standard length in Cichla spp. and Geophagus surinamensi and total $\mathrm{Hg}$ in unfiltered water samples from Balbina and Tucuruí reservoirs. (N corresponds to the number of fish specimens collected)

\begin{tabular}{|c|c|c|c|c|c|}
\hline \multirow[t]{2}{*}{ Sample } & \multirow{2}{*}{$\begin{array}{l}\text { Sampling } \\
\text { area }\end{array}$} & \multicolumn{2}{|c|}{ Concentration } & \multirow[b]{2}{*}{$\begin{array}{c}\text { Percent }[\mathrm{MeHg} / \mathrm{Hg}] \\
\text { Mean } \\
(\text { min-max })\end{array}$} & \multirow[b]{2}{*}{$\begin{array}{c}\text { Conc. Hg normalized at } \\
\text { standard length } /\left(\mu \mathrm{g} \mathrm{kg}^{-1}\right) \\
\text { Mean } \pm \mathrm{SD}\end{array}$} \\
\hline & & $\begin{array}{l}\text { Conc. } \mathrm{Hg} \\
\text { Mean } \pm \text { SD } \\
(\min -\max )\end{array}$ & $\begin{array}{c}\text { Conc. } \mathrm{MeHg} /\left(\mu \mathrm{g} \mathrm{kg}^{-1}\right) \\
\text { Mean } \pm \mathrm{SD} \\
(\min -\max )\end{array}$ & & \\
\hline \multirow[t]{2}{*}{ Unfiltered water } & Balbina & $\begin{array}{l}2.2 \pm 0.5 \mathrm{ng} \mathrm{L}^{-1} \\
\quad(1.3-2.8)\end{array}$ & - & - & - \\
\hline & Tucuruí & $\begin{array}{l}12.7 \pm 8.4 \mathrm{ng} \mathrm{L}^{-1} \\
\quad(4.7-28.2)\end{array}$ & - & - & - \\
\hline \multirow[t]{2}{*}{$\begin{array}{l}\text { Geophagus } \\
\text { surinamensis }\end{array}$} & Balbina & $\begin{array}{c}69.5 \pm 19.8 \mu \mathrm{g} \mathrm{kg}^{-1} \\
(47.5-105.7)\end{array}$ & $\begin{array}{l}62.8 \pm 24.9 \\
(25.1-111.2)\end{array}$ & $\begin{array}{c}96 \\
(82-106)\end{array}$ & $63.9 \pm 14.3^{*}$ \\
\hline & Tucuruí & $\begin{array}{c}63.3 \pm 37.7 \mu \mathrm{g} \mathrm{kg}^{-1} \\
\quad(11.1-171.9)\end{array}$ & $\begin{array}{c}60.1 \pm 35.7 \\
(10.6-163.3)\end{array}$ & $\begin{array}{c}95 \\
(80-107)\end{array}$ & $66.1 \pm 44.4^{*}$ \\
\hline \multirow[t]{2}{*}{ Cichla spp. } & Balbina & $\begin{array}{c}251.6 \pm 158.4 \mu \mathrm{g} \mathrm{kg}^{-1} \\
(70.4-722.5)\end{array}$ & $\begin{array}{c}245.8 \pm 159.7 \\
(63.0-727.0)\end{array}$ & $\begin{array}{c}97 \\
(89-105)\end{array}$ & $465.6 \pm 460.7 * *$ \\
\hline & Tucuruí & $\begin{array}{c}546.7 \pm 555.4 \mu \mathrm{g} \mathrm{kg}^{-1} \\
(109.8-3350.1)\end{array}$ & $\begin{array}{c}505.2 \pm 528.1 \\
(110.0-3182.5) \\
\end{array}$ & $\begin{array}{c}96 \\
(71-110) \\
\end{array}$ & $500.1 \pm 441.3^{* *}$ \\
\hline
\end{tabular}

* and ** $p>0.05$ (not significant).

concentrations in unfiltered water samples were higher (25.4-34.9 $\left.\mathrm{ng} \mathrm{L}^{-1}\right)$ as compared to the Downdam station (2.1-5.4 ng L $\left.{ }^{-1}\right){ }^{4}$ Unfiltered Balbina and Tucuruí water presented total $\mathrm{Hg}$ concentrations similar to those found at the Downdam station of Petit-Saut reservoir.

The Mann Whitney $U$ test analysis demonstrated a significant difference $(\mathrm{Z}=-3.18 ; p=0.001)$ for total $\mathrm{Hg}$ concentration between unfiltered water samples from Balbina and Tucuruí reservoirs. Total $\mathrm{Hg}$ in unfiltered Tucuruí water samples was approximately 6 times higher than that found in Balbina reservoir.

According to Aula et al. ${ }^{24}$ gold mining areas situated in the region of the Tucuruí reservoir are polluting the reservoir mainly via the Tocantins River. Tucuruí is formed by the Tocantins River (4\%), the Araguaia River (40\%) and the Itacaiúnas River (5\%). ${ }^{25}$

\section{Fish muscle samples}

Significant relationships were found between logtransformed body weight (W) of fish species, Cichla spp. and $G$. surinamensis, and their log-transformed standard length (L) ( $p<0.05$; see Table 2).

To evaluate the body weight of Cichla spp. and G. surinamensis from the two reservoirs (Balbina and Tucuruí), we used the relationships between body weight and standard length of Cichla spp. and G. surinamensis (Table 2) to calculate a mass at the overall mean standard length of $275 \mathrm{~mm}$ and $161 \mathrm{~mm}$, respectively.

The body weight of approximately $394 \mathrm{~g}$ calculated for Cichla spp. (piscivorous fish) of Tucuruí reservoir was higher than the estimated values of $336 \mathrm{~g}$ for fish from the Balbina reservoir. The body weight of approximately $130.4 \mathrm{~g}$ and $130.7 \mathrm{~g}$ calculated for G. surinamensis (omnivorous fish) of Balbina and Tucuruí reservoirs did not present a significant difference between them.

The higher body weight found in Cichla spp. from the Tucuruí reservoir could be because its ecosystem is a more productive ecosystem, mesotrophic, with high phytoplankton densities and also higher nutrients concentrations $(\mathrm{C}, \mathrm{N}, \mathrm{P})$ than in oligotrophic Balbina reservoir. ${ }^{20}$ In the Tucuruí reservoir, the density of microorganisms in the water column associated with a high accumulation of organic matter results in high primary production water and more prey items for Cichla. This genus is opportunistic in terms of prey selection. ${ }^{15} \mathrm{At}$ the beginning of its life, this genus is planktivorous, then carnivorous and, in the mature stage, piscivorous. Cichla spp. capture larger, likely more contaminated prey items as they grow, i.e. with increasing standard length. In this study, most of the specimens analyzed were in the sexually mature stage; as the maturation of Cichla spp. for both sexes occurs at approximately $200-350 \mathrm{~cm}$. However, studies of diet composition in one location are not necessarily directly applicable to another. Fish feeding behaviour adapts to changes in habitat due to seasonal inundation of the forest.

Piscivorous species, which are at the top of aquatic food chains, are a good indicator of mercury contamination in fish. ${ }^{26}$ Amongst the data generated as part of the present study, only 3 specimens (3\%) of the samples of Cichla spp. muscle presented a total mercury concentration higher than the maximum permissible limit of $1.0 \mu \mathrm{g} \mathrm{g}^{-1}$ wet wt. 
established for human consumption of predatory fish in Brazil. ${ }^{27}$ Meanwhile, 31 fish samples analyzed (22\%) had $\mathrm{MeHg}$ concentrations above the maximum limit of $0.5 \mu \mathrm{g}$ $\mathrm{Hg} \mathrm{g}^{-1}$ wet wt. established for food by the WHO. ${ }^{28}$ This does not mean, however, that there is lower risk to human health, as the early signs of the neurotoxic effects that could be related to $\mathrm{MeHg}$ exposure from fish consumption have been shown in at least one riverine community in the Tapajós River basin. These signs of neurotoxic effects could be related to methylmercury exposure from fish consumption. ${ }^{1,29}$

Range (min-max) and mean concentrations, on a wet weight basis, of total mercury $(\mathrm{Hg})$ and methylmercury $(\mathrm{MeHg})$ and the ratios of $\mathrm{MeHg}$ to total $\mathrm{Hg}(\mathrm{MeHg} / \mathrm{Hg})$ in Cichla spp. and Geophagus surinamensis are presented in Table 4.

Total $\mathrm{Hg}$ and $\mathrm{MeHg}$ concentrations in the 95 muscle samples of Cichla spp. ranged from 0.07 to $3.35 \mu \mathrm{g} \mathrm{Hg} \mathrm{g}^{-1}$ wet wt. and from 0.06 to $3.18 \mu \mathrm{g} \mathrm{MeHg} \mathrm{g}^{-1}$ wet wt. Total $\mathrm{Hg}$ and $\mathrm{MeHg}$ concentrations in the 130 muscle samples of G. surinamensis ranged from 0.01 to $0.17 \mu \mathrm{g} \mathrm{Hg} \mathrm{g}^{-1}$ wet wt. and from 0.01 to $0.16 \mu \mathrm{g} \mathrm{MeHg} \mathrm{g}^{-1}$ wet wt. In this study, total $\mathrm{Hg}$ and $\mathrm{MeHg}$ concentrations found in the muscle samples of Cichla spp. and G. surinamensis were of the same order of magnitude as those reported in earlier studies with Amazonian freshwater fishes from Brazil, 2,3,30,31 Suriname ${ }^{32}$ and French Guiana. ${ }^{4}$ In addition, recent mercury data compared with those of 15 years ago from the Tucuruí area showed a reduction in mercury concentrations by a factor of two or three times for piscivorous fish, including Cichla spp. ${ }^{25}$

The Kruskal-Wallis ANOVA analysis demonstrated highly significant differences for $\mathrm{Hg}$ and $\mathrm{MeHg}$ concentrations between the muscle of all fish species (omnivorous and piscivorous) from Balbina ( $\mathrm{H}=15.4$; $p \ll 0.001)$ and Tucuruí $(\mathrm{H}=138.1 ; p \ll 0.001)$ reservoirs.

The mean total $\mathrm{Hg}$ concentration in muscle tissue was higher, and more variable, in the piscivorous fish than in the omnivorous fish (Table 4). Total Hg concentrations varied widely among the investigated species. Cichla spp., which feeds mainly on fish species, presented the highest total $\mathrm{Hg}$ value, approximately 9 times and 4 times higher than those values found in Geophagus surinamensis from Tucuruí and Balbina reservoirs, respectively. This finding is consistent with earlier observations on the biota of Amazon Basin. ${ }^{2,4,33,34}$ According to Dórea and Barbosa, ${ }^{2}$ a wide variation in fish mercury bioaccumulation is expected in the complex and biologically dense environment of the Amazon rain forest.

Regarding mercury dietary intake, which can influence mercury uptake in freshwater organisms, there is a marked difference between the concentrations within fish species. Furthermore, the variability of total $\mathrm{Hg}$ in the different fish species is likely to reflect both interspecies dietary differences, with correspondingly different total $\mathrm{Hg}$ levels, and age-related accumulation trends. ${ }^{34}$

Piscivorous and omnivorous fishes showed similar ratios of methylmercury/total mercury $(\mathrm{MeHg} / \mathrm{Hg})$ in muscle tissue, of around $100 \%$ in both reservoirs (see Table 4). Total Hg in muscle tissue was found essentially in the form of organic mercury, as $\mathrm{MeHg}$, in agreement with previously reported values for piscivorous and omnivorous fish of the Brazilian Amazon. 3,30,35 According to Watras et al. ${ }^{36}$ methylmercury concentrations at higher trophic levels reflect an uptake from lower trophic levels; among others, involving such factors as diet and growth. Due to its lengthy persistence and high mobility in the aquatic ecosystem, methylmercury shows a high level of biomagnification in the upper levels of the food chain.

The Mann-Whitney $U$ test demonstrated a highly significant difference $(Z=86.0 ; p<0.001)$ between the analyzed $\mathrm{MeHg}$ of muscle tissue from the piscivorous and the omnivorous fish from Tucuruí $(\mathrm{Z}=11.8 ; p$ « 0.001) and Balbina reservoirs $(Z=3.9 ; p \ll 0.001)$, respectively.

$\mathrm{MeHg}$ increased successively with increasing trophic level, from the omnivorous fish to the piscivorous fish (Table 4). This indicates that biomagnification may be occurring along the Balbina and Tucuruí food chains. This finding is consistent with early observations on the biota of Amazon Basin. ${ }^{4,30}$ Biomagnification is defined as the increasing concentration of a trace element at successively higher trophic levels of a food chain, i.e. when the concentrations in the tissues of one organism exceed those in its food source. ${ }^{37,38}$ Biomagnification of $\mathrm{MeHg}$ in aquatic food chains is well known and is evident in repeated observations of the highest concentrations in large, longlived, upper trophic level animals. The trophic level is of extreme importance among the ecological factors that control mercury, such as MeHg levels in different fish species. ${ }^{34}$

Significant and positive correlations were found between total $\mathrm{Hg}$ and $\mathrm{MeHg}$ concentrations in Cichla spp., a piscivorous fish species, and their body weight (W) (log-transformed) or standard length $(\mathrm{L})(p<0.05)$, (see Table 5, Figure 2). While Hg concentration showed a linear increase with standard length and body weight (see Figure 2a), the concentration of methylmercury exhibited a linear increase with standard length and a body weight (see Figure 2b). Total $\mathrm{Hg}$ and $\mathrm{MeHg}$ exhibited highly significant coefficients of correlation $\left(r^{2}=0.73\right.$ and $\mathrm{r}^{2}=0.59$, respectively) with the standard length of Cichla spp.; whereas concentrations presented low coefficients of correlation $\left(\mathrm{r}^{2}=0.18\right.$ for $\mathrm{Hg}$ and $\mathrm{r}^{2}=0.16$ for $\left.\mathrm{MeHg}\right)$ 
Table 5. Regression relationships between total mercury $(\mathrm{Hg})$ and methylmercury $(\mathrm{MeHg})$ concentrations ( $\mu \mathrm{g} \mathrm{g}^{-1}$ wet wt.) in muscle and body weight or standard length of the fish species. ( $\mathrm{N}$ corresponds to the total number of fish specimens collected)

\begin{tabular}{|c|c|c|c|}
\hline Species & $\mathrm{N}$ & $\begin{array}{c}\text { Relation } \\
\text { concentration and } \mathrm{W}\end{array}$ & Relation concentration and $\mathrm{L}$ \\
\hline \multirow[t]{2}{*}{ Cichla spp. } & 95 & $\begin{array}{c}{[\mathrm{Hg}]=0.8 * \mathrm{~W}+175.0} \\
\mathrm{r}^{2}=0.18 ; p<0.001\end{array}$ & $\begin{array}{c}{[\mathrm{Hg}]=6.4 * \mathrm{~L}-1252.1} \\
\mathrm{r}^{2}=0.73 ; p<0.0001\end{array}$ \\
\hline & & $\begin{array}{c}{[\mathrm{MeHg}]=350 * \log \mathrm{W}-517.0} \\
\mathrm{r}^{2}=0.16 ; p<0.02\end{array}$ & $\begin{array}{c}{[\mathrm{MeHg}]=1.5 * \mathrm{~L}-37.5} \\
\mathrm{r}^{2}=0.59 ; p<0.0001\end{array}$ \\
\hline \multirow[t]{2}{*}{ Geophagus surinamensis } & 130 & $\begin{array}{c}{[\mathrm{Hg}]=-16.4 * \log \mathrm{W}+98.3} \\
\mathrm{r}^{2}=0.08 ; p>0.10\end{array}$ & $\begin{aligned} {[\mathrm{Hg}] } & =-31 * \log \mathrm{L}+132.3 \\
\mathrm{r}^{2} & =0.11 ; p=0.05\end{aligned}$ \\
\hline & & $\begin{array}{c}{[\mathrm{MeHg}]=-44 * \log \mathrm{W}+165.0} \\
\mathrm{r}^{2}=0.06 ; p>0.10\end{array}$ & $\begin{array}{c}{[\mathrm{MeHg}]=-0.3 * \mathrm{~L}+118.0} \\
\mathrm{r}^{2}=0.04 ; p>0.10\end{array}$ \\
\hline
\end{tabular}

with body weight. The concentration of mercury is best correlated with the fish length, since length does not decrease with time, while body weight sometimes does. ${ }^{39}$ The methylmercury concentration at higher trophic levels reflects the uptake at lower trophic levels and other factors such as diet and growth. ${ }^{36}$

However, no significant relationships $(p » 0.05)$ were found between biological characteristics (L and W) of $G$. surinamensis, an omnivorous fish species, and muscular total $\mathrm{Hg}$ and $\mathrm{MeHg}$ (see Table 5).

Total mercury and methylmercury concentrations in the Cichla spp. muscle were subjected to length normalization in order to compare their levels between Balbina and Tucuruí reservoirs, due to the different mean standard length (L) of the fish sampled in both reservoirs (Table 2).

In this case, we normalized the concentrations of total $\mathrm{Hg}$ and $\mathrm{MeHg}$ using the regression equations, $[\mathrm{Hg}]=6.4 \mathrm{~L}-$ 1252.2 and $[\mathrm{MeHg}]=1.5 \mathrm{~L}-37.5$. These regression equations presented significant relationships $\left(\mathrm{r}^{2}=0.73\right.$ for $\mathrm{Hg}$ and $\mathrm{r}^{2}=$ 0.59 for $\mathrm{MeHg}, p<0.0001)$ between concentrations of total $\mathrm{Hg}$ and $\mathrm{MeHg}$ and standard length (L) of the 95 specimens of Cichla spp. The range and mean of length-normalized concentrations of total $\mathrm{Hg}$ are summarized in Table 4. Concentrations of total $\mathrm{Hg}$ and $\mathrm{MeHg}$ at a standard size were also reported by Sorensen et al. ${ }^{40}$ and Kehrig et al. ${ }^{3}$

We normalized the concentrations of total $\mathrm{Hg}$ and $\mathrm{MeHg}$ in G. surinamensis using a mean fish length of $161 \mathrm{~mm}$ that corresponds to the mean of standard length of the 130 specimens of this omnivorous fish. The mean fish length was used due to no significant difference was found between body weights and standard lengths of this fish species collected at the Balbina and Tucuruí reservoirs.

Differences in growth rate between fish populations in this study are a potential explanation for variations in total $\mathrm{Hg}$ and $\mathrm{MeHg}$ concentrations. Fish growth rates may affect mercury accumulation by changing the balance between the rate of deposition of new tissue and the gut adsorption efficiencies for both nutrients and $\mathrm{MeHg}{ }^{3}$

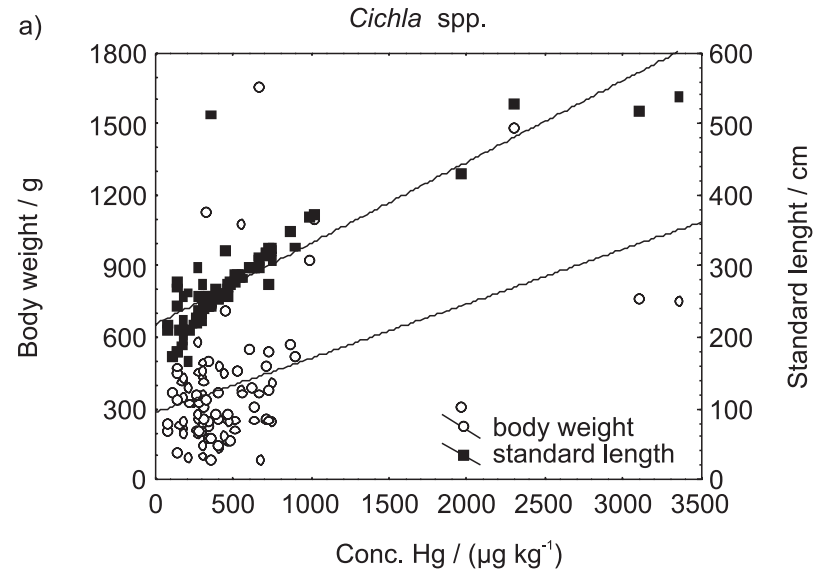

b)

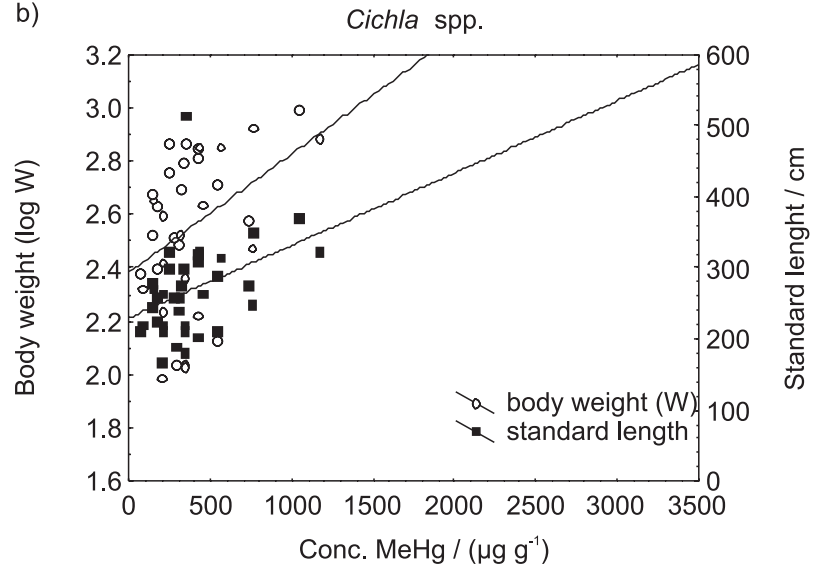

Figure 2. Relationship between total mercury (a) and methylmercury (b) concentrations in all specimens of Cichla spp. $(\mathrm{N}=95)$ and their biological parameters [log (body weight) and standard length] collected at Balbina and Tucuruí reservoirs.

The $U$ test revealed no significant differences between the Balbina and Tucuruí reservoirs for the normalized concentrations of total $\mathrm{Hg}(\mathrm{N}=95 ; \mathrm{Z}=0.29 ; p>0.50)$ and $\mathrm{MeHg}(\mathrm{Z}=0.095 ; p>0.50)$ in Cichla spp. We also found no significant difference $(Z=0.016 ; p>0.50)$ in the ratios of $\mathrm{MeHg}$ to total $\mathrm{Hg}$ between these two reservoirs of Brazilian Amazon. 
Similarly the $U$ test also revealed no significant differences among Balbina and Tucuruí reservoirs for the normalized concentrations of total $\mathrm{Hg}(\mathrm{N}=130 ; \mathrm{Z}=0.73$; $p>0.50)$ and $\mathrm{MeHg}(\mathrm{Z}=-1.57 ; p>0.10)$ in G. surinamensis, as well as no significant difference $(Z=-0.25 ; p>0.50)$ in the ratios of $\mathrm{MeHg}$ to total $\mathrm{Hg}$ between both these reservoirs of Brazilian Amazon.

\section{Bioconcentration factor}

Mercury in the muscle of fish is mainly the result of bioaccumulation and biomagnification of $\mathrm{MeHg}$ along the aquatic food chain. ${ }^{41}$ According to Reinfelder et al. ${ }^{42}$ the uptake of mercury from the dissolved water phase is a significant pathway for bioaccumulation of contaminants by aquatic organisms that present smaller body size and higher superficial relative area, such as plankton. The increase of the body size of the aquatic organisms, such as fish, decreases the rate of uptake of dissolved mercury from the water; consequently the trophic transfer of mercury becomes the most efficient pathway for its accumulation. ${ }^{42}$ Fish assimilate mercury mainly by ingestion of food, which may vary according to the concentration of mercury in fish prey.

Bioconcentration is defined as the uptake of a chemical by an organism from the abiotic environment resulting in a higher concentration within the organism. ${ }^{37}$ In this study, the bioconcentration factor (BCF) was calculated as the relation between the total $\mathrm{Hg}$ concentration in the muscle samples of Cichla spp. and Geophagus surinamensis and the total $\mathrm{Hg}$ concentration of the unfiltered water samples from Balbina and Tucuruí reservoirs, i.e. $[\mathrm{Hg}]_{\text {fish }} /[\mathrm{Hg}]_{\text {water }}$. $\mathrm{BFC}$ was used to compare mercury concentrations in water and fish between Balbina and Tucuruí reservoirs since it could reflect the bioavailability of mercury in both reservoirs. It is known that water chemistry influences the bioaccumulation of mercury by primary producers, phytoplankton at the bottom of the food chain. Plankton ultimately determine the resultant levels in higher trophic organisms, such as fish. ${ }^{43}$

The bioconcentration factor observed, relative to the total $\mathrm{Hg}$ concentration in Cichla spp. collected at Balbina reservoir and its water samples $\left(11.4 \times 10^{4}\right)$ was 4 times higher than that found for Geophagus surinamensis $\left(31.6 \times 10^{3}\right)$ from the same ecosystem. The BCF observed relating to the total $\mathrm{Hg}$ concentration by Cichla spp. collected at Tucuruí reservoir and its water samples $\left(4.3 \times 10^{4}\right)$ was approximately 10 times higher than that found for G. surinamensis $\left(5.0 \times 10^{3}\right)$ from the same ecosystem.

The BCF increased successively with increasing trophic level, from the omnivorous fish $\left(10^{3}\right)$ to the piscivorous fish $\left(10^{4}\right)$. In this study, the piscivorous fish, Cichla spp., was a fish species that presented the highest tissue mercury concentrations, and is also the highest trophic level fish in both reservoirs. This is in agreement with an earlier study conducted at Lake Powell, a man made reservoir. ${ }^{44}$

The BCF relating to the total $\mathrm{Hg}$ concentration by Cichla spp. and G. surinamensis collected at Balbina reservoir were approximately 3 times and 6 times higher than those from Tucuruí reservoir. This may be related to differences between the aquatic environmental conditions of the Balbina and Tucuruí reservoirs.

The aquatic ecosystem of Tucuruí presented a higher process of eutrophication than Balbina reservoir. Tucuruí reservoir is a mesotrophic aquatic environment that presents macrophytes quite restricted to a few areas. ${ }^{25}$ Eutrophication may affect the biogeochemical cycling of mercury in reservoirs, playing an important role in its transport and immobilization. ${ }^{45}$ These process changes strongly affect the chemical forms of mercury that can determine the bioavailability of mercury in water. Fish in eutrophic lakes, however, were often found to contain less mercury than those in oligotrophic lakes. This phenomenon has been explained by the increasing algal biomass in eutrophic systems reducing mercury accumulation at higher trophic levels through the dilution of mercury in consumed algal cells. ${ }^{45}$

The aquatic system of Balbina reservoir presents black waters and acid $\mathrm{pH}$ (see Table 1) that are rich in natural organic matter. A number of studies have demonstrated that $\mathrm{MeHg}$ bioaccumulation is higher in lower $\mathrm{pH}$ aquatic systems ${ }^{46}$ such as Balbina reservoir. Natural organic matter interacts with mercury in several different ways, affecting the transport, transformation and bioavailability of mercury. One of the most important reactions is the formation of extremely strong ionic bonding between mercury and reduced sulphur sites in soil and aquatic organic matter. Strong complexation facilitates the mobility of mercury from natural and contaminated soils and sediments ${ }^{47}$ into streams, ${ }^{48}$ lakes,${ }^{49}$ and groundwater. ${ }^{50}$ This enhanced mobility results in increased water column concentrations of mercury in otherwise pristine lakes and streams.

In most freshwaters, the predominant form of mercury is ionic mercury in the divalent state ( $\mathrm{Hg}$ II), whereas in most muscle fish species $>95 \%$ of mercury is in the form of methylmercury $\left(\mathrm{MeHg}=\mathrm{CH}_{3} \mathrm{Hg}^{+}\right)$. Thus, conversion of ionic mercury to methylmercury is an important link in the bioaccumulation of mercury in fish and ultimately its toxicity to wildlife and humans. $\mathrm{MeHg}$ production in aquatic systems is not a simple function of total $\mathrm{Hg}$ concentration in the system, and $\mathrm{MeHg}$ concentrations in aquatic environments are seldom related to total mercury load. Mercury methylation is mainly a microbially mediated 
process, with abiotic methylation likely to be important in organic-rich lakes. ${ }^{51}$ Once methylmercury is formed, dissolved organic matter (DOM) facilitates its solubility (thus increasing the water column concentration) and transport through complexation. ${ }^{52}$ Apart from the role of DOM, mercury methylation and bioaccumulation rates in aquatic systems are influenced by a large number of complexes, inter-related environmental variables, such as biological activity, nutrient availability, $\mathrm{pH}$, temperature, redox potential, and inorganic and organic complexing agents. ${ }^{53}$ The biological uptake of methylmercury also appears to be strongly influenced by the concentration and type of DOM present in the ecosystem. While the toxicity and bioaccumulation of most other trace metals are generally reduced by complexation with DOM, mercury bioavailability can be increased or decreased by DOM. ${ }^{53}$

Although Tucurui reservoir presented higher mercury concentrations in water than Balbina reservoir, the concentration of mercury found in fish from both reservoirs could be considered similar. Probably, this is related to the process of eutrophication that is occurring in the Tucuruí ecosystem. Eutrophication processes increase the biomass in the Tucuruí ecosystem that may subsequently dilute the mercury concentration and reduce its availability to fish species. $^{54}$

\section{Conclusions}

Relatively low concentrations of $\mathrm{Hg}$ were found in the unfiltered water samples when compared with other manmade reservoirs, mainly those from the Amazon basin. $\mathrm{Hg}$ concentrations in water samples varied according to the trophic stage of the aquatic environment and water color of the reservoir. Balbina reservoir, an oligotrophic black water ecosystem, rich in natural dissolved organic matter, presented lower mercury concentrations in water samples than Tucuruí, a mesotrophic clear water ecosystem. The increasing concentration of $\mathrm{MeHg}$ at successively higher trophic levels of the food chain of both reservoirs corresponds to a transfer between trophic levels from the lower trophic level (G. surinamensis) to the predatory (Cichla spp.), suggesting that $\mathrm{MeHg}$ was biomagnified. $\mathrm{Hg}$ and $\mathrm{MeHg}$ were positively correlated with the piscivorous fish standard length, suggesting that larger and older fish bioaccumulated more of this element. Neither Cichla spp. nor G. surinamensis presented significant differences in normalized concentrations between the reservoirs. The $\mathrm{Hg}$ bioconcentration factor increased with fish trophic level, from the omnivorous fish $\left(10^{3}\right)$ to the piscivorous fish $\left(10^{4}\right)$. However, the bioconcentration factors observed in Balbina reservoir were significantly higher than those found in
Tucuruí reservoir. Based on the results presented here, we can conclude that not only different limnological and ecological characteristics but also feeding habits lead to different patterns of accumulation of mercury as methylmercury in the muscle tissue of fish species. The different limnological and ecological characteristics of the reservoirs also influenced the concentrations of total mercury in the water column and, consequently, mercury bioaccumulation and also mercury concentration in fish muscle.

\section{Acknowledgments}

The authors would like to thank the Brazilian National Council for Scientific and Technological Development (CNPq) and ELETRONORTE for financial support, as well as for the infrastructure and logistical support provided by ELETRONORTE to carry out the fish collections. The authors also thank an anonymous referee who made significant contributions to the improvement of the manuscript during the evaluation process.

\section{References}

1. Dolbec, J.; Mergler, D.; Sousa Passos, C. -J.; Lebel, J.; Int. Arch. Occup. Environ. Health 2000, 73, 195.

2. Dórea, J. G.; Barbosa, A. C.; Biol. Trace Elem. Res. 2007, 115, 243.

3. Kehrig, H. A.; Howard, B. M.; Malm, O.; Environ. Pollut. 2008, 154, 68 .

4. Boudou, A.; Maury-Brachet, R.; Coquery, M.; Durrieux, G.; Cossa, D.; Environ. Sci. Technol. 2005, 39, 2448.

5. Verdon, R.; Brouard, D.; Demers, C.; Lalumiere, R.; Water, Air, Soil Pollut. 1991, 56, 405; Porvari P.; Sci. Total Environ. 1995, 175, 109; Schetagne, R.; Doyon, J. F.; Fournier, J. J.; Sci. Total Environ. 2000, 260, 135

6. Tuomola, L.; Niklasson, T.; Castro e Silva, E.; Hylander, L. D.; Sci. Total Environ. 2008, 390, 177.

7. Masson, S.; Tremblay, A.; Sci. Total Environ. 2003, 304, 377.

8. Fearnside, P. M.; Environ. Manage. 2001, 27, 377.

9. Verta, M.; Aqua. Fenn. 1984, 14, 215; Wasserman, J. C.; Hacon, S.; Wasserman, M. A.; Ambio 2003, 32, 336.

10. Bodaly, R. A.; Hecky, R. E.; Fudge, R. J. P.; Can. J. Fish. Aquat. Sci. 1984, 41, 682; Rudd, J. W. M.; Harris, R.; Kelly, C. A.; Hecky, R. E.; Ambio 1993, 22, 246.

11. Wright, D.A.; Mason, R.P.; Int. J. Environ. Pollut. 2000, 13, 226.

12. Roulet, M.; Lucotte, M.; Saint-Aubina, A.; Trana, S.; Rheault, I.; Farella, N.; Jesus Silvs, E.; Dezemcourt, J.; Souza-Passos, C. J.; Santos Soares, G.; Guimarães, J. R. D.; Mergler, D.; Amorim, M.; Sci. Total Environ. 1998, 223, 1; Fadini, P. S.; Jardim, W. F.; Sci. Total Environ. 2001, 275, 71. 
13. Lucotte, M.; Hillarie-Marcel, C.; Mucci, A.; Pichet, P.; Planas, D.; Van Tra, H.; Abstracts of $3^{\text {rd }}$ International Conference on Mercury as a Global Pollutant, Whistler, British Columbia, Canada, 1994.

14. Roulet, M.; Lucotte, M.; Canuel, R.; Farella, N.; De Freitas Goch, Y. G.; Pacheco Peleja, J. R.; Guimarães, J. R. D.; Mergler, D.; Amorim, M.; Limnol. Oceanogr. 2001, 46, 1141.

15. Abelha, M. C. F.; Agostinho, A. A.; Goulart, E.; Acta Sci. Biol. Sci. 2001, 23, 425; Winemiller, K. O.; Taphorn, D. C.; Barbarino-Duque, A.; Copeia 1997, 4, 690.

16. Kullander, S. O.; Ferreira E. J. G.; Ichthyol. Explor. Freshwaters 2006, 17, 289.

17. Lebel, J.; Roulet, M.; Mergler, D.; Lucotte, M., Laribe, F.; Water, Air, Soil Pollut. 1997, 97, 31; Passos, C. J. S.; Mergler, D.; Lemire, M.; Fillion, M.; Guimarães, J. R. D.; Sci. Total Environ. 2007, 373, 68.

18. Kullander, S. O.; Nijssen, H. In The Cichlids of Surinam: Teleostei, Labroidei; Brill, E. J., ed.; Brill Academic Publishers: The Netherlands, Leiden, 1997, p. 256.

19. Cabana, G.; Rasmussen, J. B.; Nature 1994, 372, 255.

20. Eletronorte; Relatório Técnico sobre o Programa de Limnologia e Qualidade da Água de Tucuruí, Brasil, 1998, p.42.; Espíndola, E. L. G.; Matsumura-Tundisi, T.; Reitzler, A. C.; Tundisi, J. G.; Rev. Bras. Biol. 2000, 60, 179.

21. Akagi, H.; Nishimura, H. In Advances in Mercury Toxicology; Suzuki, T.; Imura, N.; Clarkson, T. W., eds.; Plenum Press: New York, 1991, session 1.

22. Kehrig, H. A.; Costa, M.; Moreira, I.; Malm, O.; J. Braz. Chem. Soc. 2006, 17, 1409.

23. Maurice-Bourgoin, L.; Quiroga, I. In The Ecohydrology of South American Rivers and Wetlands; McClain, M. E., ed.; International Association of Hydrological Sciences: Wallingford, 2002.

24. Aula, I.; Braunschweiler, H.; Malin, I.; Sci. Total Environ. 1995, $175,97$.

25. Malm, O.; Palermo, E. F. A.; Santos, H. S. B.; Rebelo, M. F.; Kehrig, H. A.; Oliveira, R. B.; Meire, R. O.; Pinto, F. N.; Moreira, L. A.; Guimarães, J. R. D.; Torres, J. P. M.; Pfeiffer, W. C.; RMZ-M \& G 2004, 51, 1195.

26. Belger, L.; Forsberg, B. R.; Sci. Total Environ. 2006, 367, 452.

27. Brasil; Agência Nacional de Vigilância Sanitária-Portaria $n^{o} 685$ de 27/08/98, Brasília, Brasil, 1998.

28. WHO; Environmental Health Criteria 101, World Health Organisation: Geneva, 1990.

29. Lebel, J.; Mergler, D.; Branches, F.; Lucotte, M.; Amorim, M.; Larribe, F.; Dolbec, J.; Environ. Res. 1998, 79, 20; Grandjean, P.; White, R. F.; Nielsen, A.; Cleary, D.; Santos, E. C. O.; Environ. Health Perspect. 1999, 107, 587.

30. Kehrig, H. A.; Malm, O.; Appl. Organomet. Chem. 1999, 13, 689.

31. Bastos, W. R.; Almeida, R.; Dórea, J. G.; Barbosa, A. C.; Ecotoxicology 2007, 16, 341.
32. Mol, J. H.; Ramlal, J. S.; Lietar, C.; Verloo, M.; Environ. Res. 2000, 86, 183.

33. Dórea, J. G.; Barbosa, A. C.; Silva, G. S.; Comp. Biochem. Physiol. 2006, 142, 275; Hylander, L. D.; Gröhn, J.; Tropp, M.; Vikström, A.; Wolpher, H.; Castro e Silva, E.; Meili, M.; Oliveira, L. J.; J. Environ. Manage. 2006, 81, 155.

34. Sampaio da Silva, D.; Lucotte, M.; Davidson, R.; Environ. Res. 2009, 109, 432.

35. Akagi, H.; Malm, O.; Kinjo, Y.; Harada, H.; Branches, F. J. P.; Pfeiffer, W. C.; Kato, H.; Sci. Total Environ. 1995, 175, 85.

36. Watras, C. J.; Back, R. C.; Halvorsen, S.; Hudson, R. J. M.; Morrison, K. A.; Wente, S. P.; Sci. Total Environ. 1998, 219, 183.

37. Gray, J. S.; Mar. Pollut. Bull. 2002, 45, 46.

38. Barwick, M.; Maher, W.; Mar. Environ. Res. 2003, 56, 471.

39. Huchabee, J. W.; Elwood, J. W.; Hildebrand, S. C. In The Biogeochemistry of Mercury in the Environment; Niagru, J. O., ed.; Elsevier: Amsterdam, 1979.

40. Sorensen, J. A.; Glass, G. E.; Schmidt, K. W.; Huber, J. H.; Rapp Jr., G. R.; Environ. Sci. Technol. 1990, 24, 1716.

41. Lindqvist, O.; Johnasson, K.; Aastrup, M.; Andersson, A.; Bringmark, L.; Hovsenius, G.; Håkanson, Å.; Meili, M.; Timm, B.; Water, Air, Soil Pollut. 1991, 55, 1.

42. Reinfelder, J. R.; Fisher, N. S.; Luoma, S. N.; Nichols, J. W.; Wang, W-X.; Sci. Total Environ. 1998, 219, 117.

43. Mason, R. P.; Laporte, J. -M.; Andres, S.; Arch. Environ. Contam. Toxicol. 2000, 38, 283.

44. Potter, L.; Kidd, D.; Standiford, D.; Environ. Sci. Technol. 1975, 9,41 .

45. He, T.; Feng, X.; Guo, Y.; Qiu, G.; Li, Z.; Liang, L.; Lu, J.; Environ. Pollut. 2008, 154, 56.

46. Watras, C. J.; Bloom, N.S.; Liminol. Oceanogr. 1992, 37, 1313.

47. Wallschlager, D.; Desai, M. V.; Wilken, R. D.; Water, Air, Soil Pollut. 1996, 90, 507.

48. Mierle, G.; Ingram, R.; Water, Air, Soil Pollut. 1991, 56, 349.

49. Driscoll, C. T.; Blette, V.; Yan, C.; Schofield, C. L.; Munson, R.; Holsapple, J.; Water, Air, Soil Pollut. 1995, 80, 499.

50. Krabbenhoft, D. P.; Babiarz, C. L.; Water Resour. Res. 1992, $28,3119$.

51. Ullrich, S. M.; Tanton, T. W.; Abdrashitova, S. A.; Crit. Rev. Environ. Sci. Technol. 2001, 31, 241.

52. Miskimmin, B. M.; Bull. Environ. Contam. Toxicol. 1991, 47, 743; Hurley, J. P.; Benoit, J. M.; Babiarz, C. L.; Shafer, M. M.; Andren, A. W.; Sullivan, J. R.; Hammond, R.; Webb, D. A.; Environ. Sci. Technol. 1995, 29, 1867.

53. Ravichandran, M.; Chemosphere 2004, 55, 319.

54. Björnberg, A.; Håkanson, L.; Lundberg, K. A.; Environ. Pollut. 1988, 49, 53.

Received: January 31, 2009 Web Release Date: June 25, 2009 